\title{
Consulting Support of Technologization of Professional Practice of a Teacher
}

\author{
DZoya Lukashenia ${ }^{1}$ Candidate of Pedagogical Sciences \\ (1) Lidia Chepikova ${ }^{2}$ Candidate of Pedagogical Sciences \\ (D) Hanna Rudneva ${ }^{3}$ Master of Science in Education \\ Baranovichi State University, Republic of Belarus ${ }^{1,3}$; Smolensk State University, Russia ${ }^{2}$ \\ zvluk@mail.ru1; lidiya67@bk.ru²; anna--rud@mail.ru³
}

\begin{abstract}
The article presents the results of experimental work on consulting support of professional practice of a teacher, which introduces local innovations. These innovations are initiated by teachers who need advice on developing a project to implement them in their professional activities. Innovative changes developed by the teacher infringe the order in the implementation of existing professional practice, which leads to the need for its technologization. The presented circumstances actualize consulting support as a form of teacher training directly at the workplace. The purpose of the research stated in the publication is to identify the impact of consulting support on the formation of competencies of consulted ones on the implementation of local innovations developed by them in their own professional practice. Consulting support of technologization by teachers-clients of their own professional practice, after the introduction of local innovative changes, was implemented in a mixed type, combining offline and online formats. The authors of the publication propose to evaluate the success of participants in consulting support for the products developed in its process: the project of technologization of professional practice and the program for its implementation. The obtained data were statistically processed using the parametric method of variance analysis. Statistical processing of the data obtained confirmed the effectiveness of this approach. Professional growth and motivation of educational institution specialists are regulated with statistical accuracy by consulting, which acts as an educational management practice. The consulting on the development of local innovations should be carried out continuously to support the teacher's strategically significant needs, and not just their fragmentary situational requests.
\end{abstract}

Keywords: continuing education of a teacher, technologization of professional activities, consulting support, consulting in education.

\section{Introduction}

The relevance of the research presented in this article is due to the exponential development of technologies, which implies the activation of the development of subjects in the field of education in the areas defined by the main trends of qualitative changes in modern society. Since the end of the last century, research in the field of professional education, that reveals the diversity and contrast of their interpretation and identifies the problems that arise in their implementation (Watkins, 1995; Niemi, 1985), has been intensified to find the forms of training specialists in their workplace. These studies continue throughout this century, revealing the issues that shape education based on the analysis of the main economic, political, social and technological trends as factors that have a significant impact on the preparation of society for the era of artificial intelligence (Briede et al., 2020; Smith, 2017; OECD, 2019;). One of the vectors of research in this area is the implementation of educational processes considering the values of joint leadership of managers and subordinates while introducing innovations into the professional practice of specialists (Otter, Paxton, 2017).

This case study analyses the practice of consulting support for the technologization of pedagogical activities of specific teachers who have completed a refresher course at the Federal State Budgetary Educational Institution of Higher Education «Smolensk State University».

When organizing and implementing consulting support, we were guided by the leading ideas of foreign colleagues who are engaged in the research on the impact of consulting on the client's experience (Parikh, 2015; Portere, Briede, 2019), opportunities for providing online consulting services (Garza, Mundy, Kupczynski, 2018; Urdzina-Merca, Dislere, 2018), analysis of the assessment of its consequences (Dislere, Vronska, 2020; Phillip, Trotter, Phillips, 2015), problems of forming technological literacy (Hasse, 2017) and technological culture of teachers (Adam, 2017). 
Consulting support for the technologization of the teacher's professional practice after the introduction of local innovation was carried out according to the model which we developed (Lukashenia, Sianiuta, 2020), using gamification (Lukashenia, Levanova, Tamarskaia, 2020). The approach developed by us correlates with the conclusions available in scientific research on the productivity of simulation activities for the development of professional competence of specialists (Cook, 2018). We rely on the researchers' conclusions about the need to create communities of practicing teachers whose performance assessment necessarily includes self-assessment (Danielson, 2016; Offen, Sandretto, 2019).

The purpose of the research stated in the publication is to identify the impact of consulting support on the formation of competencies of consulted ones on the implementation of local innovations developed by them in their own professional practice. As visualized indicators that confirm the formation of the declared competencies of the consulted ones, we have accepted the success of their passing stages and procedures of consulting on the technologization of their own professional activities in the changed conditions. The products of visualization of these indicators in our research are the projects of technologization of the professional practice and the program of its implementation developed independently by the participants in the process of consulting.

\section{Methodology}

All 97 participants in the consulting events were divided into several groups: three groups (43 people) full-time training and three groups (54 people) - part-time training in the direction 44.03.02 "Psychological and pedagogical education". Consulting support of technologization by teachers-clients of their own professional practice after the introduction of local innovative changes was implemented in a mixed type, combining offline and online formats, according to the program presented in Table 1.

Table 1

The program of consulting support of the professional practice of teachers.

\begin{tabular}{|c|c|c|}
\hline Consulting event & Teaching consulting & Process consulting \\
\hline \multirow{2}{*}{$\begin{array}{l}\text { Development of } \\
\text { a model of } \\
\text { innovative changes } \\
\text { at the local level } \\
\text { implemented in } \\
\text { professional practice }\end{array}$} & \multirow[t]{2}{*}{$\begin{array}{l}\text { Classification of innovations in the } \\
\text { pedagogical sphere }\end{array}$} & $\begin{array}{l}\text { Analysis of the innovative development } \\
\text { strategy of an educational institution }\end{array}$ \\
\hline & & $\begin{array}{l}\text { The procedure for correlating innovations } \\
\text { initiated by the clients with the strategy of } \\
\text { innovative development of an educational } \\
\text { institution (SWOT-analysis). }\end{array}$ \\
\hline \multirow{2}{*}{$\begin{array}{l}\text { Development of } \\
\text { a model of } \\
\text { professional practice } \\
\text { modified at the local } \\
\text { level }\end{array}$} & $\begin{array}{l}\text { Educational technology and related } \\
\text { categories. }\end{array}$ & $\begin{array}{l}\text { Analysis of the implemented pedagogical } \\
\text { system and its schematization. }\end{array}$ \\
\hline & $\begin{array}{l}\text { Technological characteristics of the } \\
\text { didactic category "approach". }\end{array}$ & $\begin{array}{l}\text { Design of an ideal system of intended } \\
\text { pedagogical activity, in which innovations } \\
\text { initiated by clients are implemented. }\end{array}$ \\
\hline \multirow{4}{*}{$\begin{array}{l}\text { Development of the } \\
\text { process of } \\
\text { technologization of } \\
\text { the changed } \\
\text { professional practice } \\
\text { at the local level }\end{array}$} & $\begin{array}{l}\text { Possibilities of using pedagogical techno- } \\
\text { logies based on the theory of learning } \\
\text { differentiation in professional activities }\end{array}$ & \multirow{2}{*}{$\begin{array}{l}\text { Development of a project and program for } \\
\text { technologization of the client's teaching } \\
\text { practice, in which the innovation initiated } \\
\text { by the client is implemented }\end{array}$} \\
\hline & $\begin{array}{l}\text { Possibilities of using pedagogical techno- } \\
\text { logies based on the theory of developing } \\
\text { learning in professional activities }\end{array}$ & \\
\hline & $\begin{array}{l}\text { Possibilities of using pedagogical techno- } \\
\text { logies based on the theory of program- } \\
\text { med learning in professional activities }\end{array}$ & \multirow{2}{*}{$\begin{array}{l}\text { Development of a project and program for } \\
\text { technologization of the client's teaching } \\
\text { practice, in which the innovation initiated } \\
\text { by the client is implemented }\end{array}$} \\
\hline & $\begin{array}{l}\text { Possibilities of using pedagogical techno- } \\
\text { logies based on the theory of gradual } \\
\text { assimilation of knowledge and collective } \\
\text { learning in professional activities }\end{array}$ & \\
\hline
\end{tabular}

The activity of implementing a consulting event is a closed cycle (normative ring), which consists of a system of consecutive types of activities: goal setting (G) - design (D) - action (E) - analysis as an awareness of a new situation that has arisen as a result of the action (A). While conducting consulting 
support for the formation of the technological culture of participating teachers, we considered it sufficient to divide the normative ring into sixteen parts: at each of the stages presented above, participants carry out activities similar to their sequence. The states that participants in consulting events live in our study, moving along such a normative ring, are shown in Table 2.

Table 2

Stages of a closed cycle of consulting procedures

\begin{tabular}{|c|c|c|}
\hline $\begin{array}{l}\text { Type of } \\
\text { activity }\end{array}$ & The name of the stage & Functions of the stage \\
\hline \multirow{4}{*}{ 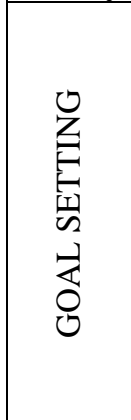 } & $\mathrm{gG}$ - motivation stage & $\begin{array}{l}\text { encourages the client participant to engage in consulting activities to } \\
\text { develop a project for making innovative changes to their own practice; }\end{array}$ \\
\hline & $\begin{array}{l}\mathrm{dG} \text { - stage of forming ideas } \\
\text { about the goal (goals) }\end{array}$ & $\begin{array}{l}\text { independent formulation by the client participant of the tasks that are } \\
\text { supposed to be solved during the implemented consulting procedure; }\end{array}$ \\
\hline & $\begin{array}{l}\text { eG - stage of direct goal } \\
\text { formation }\end{array}$ & $\begin{array}{l}\text { the client participant independently formulates and arranges the goals } \\
\text { according to the degree of significance for the consultant; }\end{array}$ \\
\hline & $\begin{array}{l}\text { aG - stage of the analysis of } \\
\text { consulting activity goals }\end{array}$ & $\begin{array}{l}\text { reflexive understanding of the structure of the developed goals by the } \\
\text { client participant for their compliance with the motive of their } \\
\text { participation in consulting; }\end{array}$ \\
\hline \multirow{4}{*}{ 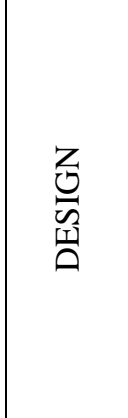 } & $\begin{array}{l}\mathrm{gD}-\text { stage of motivation to } \\
\text { get involved in the activity } \\
\text { of action design }\end{array}$ & $\begin{array}{l}\text { encourages the client participant to engage in innovative changes in } \\
\text { their professional practices; }\end{array}$ \\
\hline & $\begin{array}{l}\mathrm{dD} \text { - stage of forming ideas } \\
\text { about projecting }\end{array}$ & $\begin{array}{l}\text { independent planning by the client participant in the design process } \\
\text { of their professional activities; }\end{array}$ \\
\hline & $\begin{array}{l}\text { eD - stage of creating of the } \\
\text { project of actions }\end{array}$ & $\begin{array}{l}\text { independent design of the process of introducing local innovations in } \\
\text { their own professional practice by the client participant; }\end{array}$ \\
\hline & $\begin{array}{l}\text { aD - stage of analysis of the } \\
\text { developed project }\end{array}$ & $\begin{array}{l}\text { reflexive understanding of the developed project by the client } \\
\text { participant regarding its technological productivity; }\end{array}$ \\
\hline \multirow{4}{*}{ 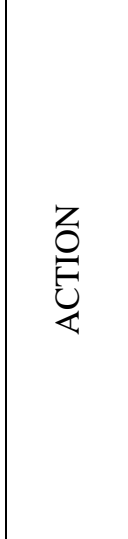 } & $\begin{array}{l}\mathrm{gE}-\text { stage of motivation to } \\
\text { start acting }\end{array}$ & $\begin{array}{l}\text { the decision making of the client participant to engage in game } \\
\text { modelling of possible changes of an innovative nature in their own } \\
\text { professional activities }\end{array}$ \\
\hline & $\begin{array}{l}\mathrm{dE}-\text { decision-making stage } \\
\text { for choosing a participation } \\
\text { position }\end{array}$ & $\begin{array}{l}\text { independent selection of a specific position ("spectator", "actor", } \\
\text { "screenwriter") by a participant-client in game modelling; }\end{array}$ \\
\hline & $\begin{array}{l}\text { eE - stage of action } \\
\text { implementation in } \\
\text { gamification }\end{array}$ & $\begin{array}{l}\text { the work of a client participant in the game modelling within a } \\
\text { specific position ("viewer", "actor", " screenwriter»); }\end{array}$ \\
\hline & $\begin{array}{l}\mathrm{aE}-\text { stage of situational } \\
\text { analysis of the completed } \\
\text { action }\end{array}$ & $\begin{array}{l}\text { reflexive awareness of the process of participation in game modelling } \\
\text { by the client participant; }\end{array}$ \\
\hline \multirow{4}{*}{ 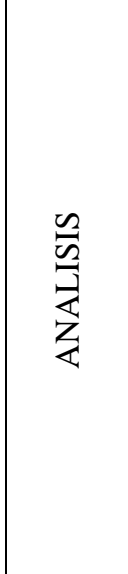 } & $\begin{array}{l}\text { gA - stage of motivation to } \\
\text { analyse actions performed in } \\
\text { game modelling }\end{array}$ & $\begin{array}{l}\text { formation of the client participant's motivation to analyse the results of } \\
\text { the actions carried out in game modelling to make changes in their own } \\
\text { professional activities at the level of local innovation initiated by them; }\end{array}$ \\
\hline & $\begin{array}{l}\mathrm{dA}-\text { stage of understanding } \\
\text { how to analyse actions per- } \\
\text { formed in game modelling }\end{array}$ & $\begin{array}{l}\text { designing the process of analysing completed actions by using } \\
\text { project development activities as the basic process; }\end{array}$ \\
\hline & $\begin{array}{l}\text { eA - stage of analysis of } \\
\text { actions performed in game } \\
\text { modelling }\end{array}$ & $\begin{array}{l}\text { analysis of actions performed by the client participant in game } \\
\text { modelling: in compliance with the project created in the implement- } \\
\text { tation of the "design" activities; to achieve the defined objectives; in } \\
\text { the new situation arising as a result of undertaken actions; }\end{array}$ \\
\hline & $\begin{array}{l}\text { aA - stage of evaluating the } \\
\text { ways of performing the } \\
\text { analysis }\end{array}$ & $\begin{array}{l}\text { reflection of the analysis process, generation, construction of new } \\
\text { methods of analysis, goal setting, design and action. }\end{array}$ \\
\hline
\end{tabular}


The sequence of states, which are lived by actors as participants in consulting activities presented above, was included in the matrix reflecting the results of self-analysis upon passing these stages.

A similar matrix for each consulting subject was filled in by at least two experts on the base of direct observation or video recordings of the consulting event. A summary matrix of the stages of consulting procedures recognized as completed by each consulting client was accepted for statistical processing. It is compiled by correlation of the ranks of the corresponding symbols in the self-assessment and expert matrices (the corresponding symbol is assigned if it is present in the working matrix at least twice).

Next, the number of completed $(n+)$ and non-completed $(n-)$ stages of consulting procedures were recorded and the share of each of them in the total number accepted (in our case, $n=16$ ) was calculated.

As an indicator of the success of consulting procedures, we took the criterion of achievement of consulting participants (DK). It is calculated by dividing the total value of the achievement levels of each of them by the number of consulted levels (Formula 1).

where $\mathrm{N}$ - number of client participants.

$$
D K=\sum_{i=1}^{N} D \mathrm{i} / N
$$

In its turn, the level of achievements of each consulted one (i) is represented by an indicator that reflects the number of stages of consulting procedures that are recognized as completed by them $(\mathrm{n}+)$ :

$$
D i=(n+) i / n
$$

The obtained data were statistically processed using the parametric method of variance analysis.

\section{Results and Discussion}

A summary matrix of the stages of consulting procedures for making a decision by a consulting participant to make innovative changes in their activities (up to the development of the project and program), which can be considered passed by each client during three consulting events in the framework of professional development of Bulgarian teachers, was processed using the computer program STATISTIKA 8. The results of the statistical processing of the results are presented below.

According to our methodology, the statistical data were processed using the analysis of variance, so when identifying the consistency of self-assessment and expert assessment, we took into account the indicators of the coefficient matrix of the Pearson rank correlation (Table 3).

Table 3

\section{Consistency of self-assessment and expert evaluation of the consulting activities}

(Pearson correlation coefficients)

\begin{tabular}{|l|c|c|c|}
\cline { 2 - 4 } \multicolumn{1}{c|}{} & Self-assessment & Assessment of expert 1 & Assessment of expert 2 \\
\hline Self-assessment & 1.00 & 0.54 & 0.59 \\
\hline Assessment of expert 1 & 0.54 & 1.00 & 0.96 \\
\hline Assessment of expert 2 & 0.59 & 0.96 & 1.00 \\
\hline
\end{tabular}

The obtained results visualize the coincidence of the expert assessment $(r=0.96)$ and the discrepancy between the self-assessment of the participants of consulting procedures. All obtained correlations are considered significant, since their values more than $p=0.001$. However, for consistency of opinions, relationships of at least 0.9 are usually considered; in extreme cases, based on the definition of reliability in psychodiagnostics - from 0.75 . The current situation has led us to the necessity to consider the assessment and self-assessment separately, while the expert assessments for further statistical processing were combined into one general assessment (the arithmetic mean is considered)

Conditionally, the participants of the consulting events (based on the results of expert evaluation of passing the consulting stages) were divided into three groups (players, viewers, scriptwriters), which together made up the first independent variable "group". The combination of self-assessment and expert assessment makes up the second independent variable "assessment" in our study. Using the formula ((Formula 2), we determine an indicator that reflects the level of achievement of each client participant through the number of stages of consulting procedures that they have passed. As a result, we have that 
different samples are affected by different combinations of two factors. This circumstance suggests the need to use two-factor analysis of variance in our study, the results of which are presented in Table 4.

Table 4

Results of variance analysis of the results of the participants in the consulting events

\begin{tabular}{|l|c|c|c|c|c|}
\hline & SS & df & MS & F & p \\
\hline Group & 0.81 & 2 & 0.40 & 33.002 & 0.000000 \\
\hline Error & 1.15 & 94 & 0.01 & & \\
\hline Evaluator (expert) & 0.00 & 1 & 0.00 & 0.245 & 0.621998 \\
\hline Evaluator *Group & 0.06 & 2 & 0.03 & 5.377 & 0.006149 \\
\hline Error & 0.48 & 94 & 0.01 & & \\
\hline
\end{tabular}

The results of the testing for the normality (homogeneity) of variance (as the main condition for the analysis of variance) showed that not all variables in all cells of the dispersion complex are distributed normally. In this case, we adhere to the opinion of scientists about the stability of the F-test due to deviation from normality. In particular, we assume that the variances in different groups are the same (assuming that the variance is uniform). The module "analysis of Variance" contains a large set of statistical criteria that allow to detect heterogeneity of variance. However, H.R. Lindman shows that the F-criterion is quite stable with respect to violation of the assumption of uniformity of variance (Lindman, 1974, 33). If the number of observations in a cell is large enough, then the deviation from normality does not matter much due to the Central limit theorem, according to which the distribution of the average value for a large sample size is close to normal, regardless of the initial distribution (Alexander, Winne, 2009).

As can be seen from the table, the effect of the variable "assessment" indicates that the assessment of experts does not differ from the self-assessment of the consulting participants; the interaction of the variables "group" and "assessment" is significant and subject to interpretation. Comparison of all combinations of the levels of independent variables is possible using the Duncan a posteriori criterion, the calculations for which at this stage of processing the results of consulting are presented in Table 5.

Table 5

Duncan's a posteriori criterion (only statistical significance levels), calculated based on the results of the consulting support

\begin{tabular}{|l|l|c|c|c|c|c|c|}
\hline \multicolumn{1}{|c|}{ Group } & Evaluator (expert) & $\{\mathbf{1}\}$ & $\{\mathbf{2}\}$ & $\{\mathbf{3}\}$ & $\{\mathbf{4}\}$ & $\{\mathbf{5}\}$ & $\{\mathbf{6}\}$ \\
\hline Players & self-assessment (\%) & & 0.072081 & 0.083956 & 0.041500 & 0.000020 & 0.000011 \\
\hline Players & $\begin{array}{l}\text { General assessment } \\
\text { of the experts }\end{array}$ & 0.072081 & & 0.670102 & 0.447531 & 0.000011 & 0.000003 \\
\hline Viewers & self-assessment (\%) & 0.083956 & 0.670102 & & 0.616139 & 0.000003 & 0.000004 \\
\hline Viewers & $\begin{array}{l}\text { General assessment } \\
\text { of the experts }\end{array}$ & 0.041500 & 0.447531 & 0.616139 & & 0.000004 & 0.000004 \\
\hline Scriptwriters & self-assessment (\%) & 0.000020 & 0.000011 & 0.000003 & 0.000004 & & 0.002143 \\
\hline Scriptwriters & $\begin{array}{l}\text { General assessment } \\
\text { of the experts }\end{array}$ & 0.000011 & 0.000003 & 0.000004 & 0.000004 & 0.002143 & \\
\hline
\end{tabular}

According to the results of the table, expert evaluations for players and spectators do not differ $(\mathrm{p}=0.4475)$. Expert evaluation and self-evaluation did not differ for the players $(\mathrm{p}=0.0720)$ and viewers $(\mathrm{p}=0.6161)$, but the scriptwriters were more critical of themselves than the experts $(\mathrm{p}=0.0021)$. Evaluations of the group of screenwriters indicate their absolute leadership in the process of successful completion of the consulting procedures.

To clarify the assessment of the success of the participants in the consulting process, we used the results of descriptive statistics (Table 6). 
Table 6

Descriptive statistics for three groups of participants-clients of consulting support

\begin{tabular}{|c|c|c|c|c|c|c|}
\hline & \multirow{2}{*}{\multicolumn{2}{|c|}{ trust interval }} & \multirow[b]{3}{*}{$\mathrm{N}$} \\
\hline & & & & & & \\
\hline Group & Evaluator (expert) & $\begin{array}{c}\text { average } \\
\text { result }\end{array}$ & $\begin{array}{c}\text { Standard } \\
\text { error }\end{array}$ & "-95\%" & $"+95 \% "$ & \\
\hline Players & self-assessment (\%) & 0.81 & 0.01 & 0.78 & 0.84 & 50 \\
\hline Players & General assessment of the experts & 0.77 & 0.01 & 0.75 & 0.80 & 50 \\
\hline Viewers & self-assessment $(\%)$ & 0.76 & 0.02 & 0.73 & 0.79 & 35 \\
\hline Viewers & General assessment of the experts & 0.75 & 0.02 & 0.72 & 0.78 & 35 \\
\hline Scriptwriters & self-assessment $(\%)$ & 0.93 & 0.03 & 0.88 & 0.99 & 12 \\
\hline Scriptwriters & General assessment of the experts & 1.00 & 0.03 & 0.95 & 1.05 & 12 \\
\hline
\end{tabular}

The results of the table demonstrate the absence of significant differences of opinion on the assessment of the success of the participants-clients of consulting procedures by experts with their self-assessment. According to the results of the table, all groups of participants in the consulting support of the technologization of the teacher's professional practice have successfully passed all its stages.

\section{Conclusions}

The presented results of an experimental study of consulting support for the technologization of a teacher's professional practice confirm the assumption that consulting on the development of local innovations should be carried out continuously to support the teacher's strategically significant needs, and not just their fragmentary situational requests.

The obtained results allow us to conclude that it is possible to use the indicators of its productivity tested in consulting in the form of:

1) the project of technologization of professional practice of a teacher, changed in accordance with the implemented innovation, which they also developed;

2) programs for implementing the process of technologization of the teacher's changing professional practice.

The combination of self-assessment of these consulting support products with their assessment by experts not only increases the reliability of the assessment, but also helps motivate teachers to develop and implement local innovations in their own professional practice.

The results of the experimental study confirm our assumption that consulting support of the technologization of teacher's professional practice are:

1. a form of continuous learning that helps to eliminate problems of insufficient information content;

2. means of actual innovative transformation of professional activity of a teacher in accordance with the needs of external society and the needs of the subjects of educational activity;

3. means of preparing for professional and personal development in the implementation of professional practice in changed conditions, leading to a high-quality compliance of their activities with the requirements of the professional standard;

4. a rational possibility of sustainable preservation of previously formed professional and personal quality of teachers to establish a stable implementation of professional practice at a new (innovative) level of educational activity.

Professional growth and motivation of educational institution specialists are regulated with statistical accuracy by consulting, which acts as an educational management practice.

\section{Bibliography}

1. Adam A.S. (2017). Framework for Seeking the Connections between Technology, Pedagogy, and Culture: A Study in the Maldives. Journal of Open, Flexible and Distance Learning, 21(1), 35-51. Retrieved from https://www.learntechlib.org/p/180235 
2. Alexander P.A., Winne P.H. (Eds.). (2009). Handbook of Educational Psychology (2nd ed.). London: Routledge. doi: 10.4324/9780203874790

3. Briede B., Beitere-Selegovska Z., Pridane A., Boldisevica L. (2020). Development of Design Thinking in the Field of Design and Crafts. In V. Dislere (Ed.), The Proceedings of the International Scientific Conference Rural Environment. Education. Personality (REEP), 13. Jelgava: Latvia University of Life Sciences and Technologies, 359-365. doi: 10.22616/REEP.2020.043

4. Cook K. (2018). Brief Counseling Scenarios from Fictional Characters for Counselors in Training. Journal on Educational Psychology, 11(3), 43-48. Retrieved from https://eric.ed.gov/?id=EJ1173814

5. Danielson C. (2016). Creating Communities of Practice. Educational Leadership, 73(8), 18-23. Retrieved from https://eric.ed.gov/?id=EJ1100627

6. Dislere V., Vronska N. (2020). Evaluation of Career Counsellors' Competences in Career Guidance. In V. Dislere (Ed.), The Proceedings of the International Scientific Conference Rural Environment. Education. Personality (REEP), 13. Jelgava: Latvia University of Life Sciences and Technologies, 385-399. doi: 10.22616/REEP.2020.046

7. Garza K., Mundy M., Kupczynski L. (2018). Counselor Self-Efficacy: The Effects of Online Preparatory Counseling Programs. Journal on Educational Psychology, 12(1), 1-7. doi: $10.26634 /$ jpsy.12.1.14374

8. Hasse C. (2017). Technological Literacy for Teachers. Oxford Review of Education, 43(3), 365-378. doi: 10.1080/03054985.2017.1305057

9. Lindman H.R. (1974). Analysis of Variance in Complex Experimental Designs. Oxford, England: W.H. Freeman Co. Ltd.

10. Lukashenia Z., Levanova E., Tamarskaia N. (2020). Use of Gamification as a Means of Consulting Support for Continuous Professional Development of Teachers. In V. Dislere (Ed.), The Proceedings of the International Scientific Conference Rural Environment. Education. Personality (REEP), 13. Jelgava: Latvia University of Life Sciences and Technologies, 428-434. doi: 10.22616/REEP.2020.050

11. Lukashenia Z., Sianiuta N. (2020). Consulting as a pedagogical guidance technology in the continuous education of a pedagogue. In V. Lubkina, K. Laganovska, A. Kḷavinska, A. Strode (Eds.), The proceedings of the International Scientific Conference Society. Integration. Education, 5. Rezekne: Rezekne Academy of Technologies, 190-199. doi: 10.17770/sie2020vol5.4988

12. Niemi J.A. (1985). Fostering participation in learning. New Directions for Adult and Continuing Education, 1985(26), 3-12. doi: 10.1002/ace.36719852603

13. OECD. (2019). Trends Shaping Education 2019. Paris: OECD Publishing. doi: 10.1787/trends_edu-2019-en

14. Offen B., Sandretto S. (2019). Transitioning to a meaningful appraisal process: One principal's journey. Journal of Educational Leadership, Policy and Practice, 33(2), 60-71. doi: 10.21307/jelpp2018-013

15. Otter K., Paxton D. (2017). A Journey into Collaborative Leadership: Moving Toward Innovation and Adaptability. New Directions for Adult and Continuing Education, 2017(156), 33-42. doi: 10.1002/ACE.20248

16. Parikh S. (2015). The Consultant's Handbook: A Practical Guide to Delivering High-value and Differentiated Services in a Competitive Marketplace. The Atrium, UK: John Wiley and Sons Ltd. doi: 10.1002/9781119166559

17. Phillips J., Trotter W.D., Phillips P.P. (2015). Maximizing the Value of Consulting: A Guide for Internal and External Consultants. Hoboken, New Jersey, USA: John Wiley \& Sons, Inc. doi: 10.1002/9781119154846

18. Portere V., Briede B. (2019). Importance of Dialogue Nature in the Mediator's Competence. In V. Dislere (Ed.), The Proceedings of the International Scientific Conference Rural Environment. Education. Personality (REEP), 12. Jelgava: Latvia University of Life Sciences and Technologies, 146-151. doi: 10.22616/REEP.2019.018

19. Smith C. (2017). Professional Development and Professionalization in the Field of Adult Basic Education. New Directions for Adult and Continuing Education, 2017(155), 71-81. doi: $10.1002 /$ ace. 20242

20. Urdzina-Merca I., Dislere V. (2018). Information and Communication Technology-Based Career Guidance Model for Young People. In V. Dislere (Ed.), The Proceedings of the International Scientific Conference Rural Environment. Education. Personality (REEP), 11. Jelgava: Latvia University of Life Sciences and Technologies, 406-415. doi: 10.22616/REEP.2018.050

21. Watkins K. (1995). Workplace learning: Changing times, changing practices. New Directions for Adult and Continuing Education 1995(68), 3-16. doi: 10.1002/ace.36719956803 